\title{
Learning by Playing: Echo and Tact in Expanding the Verbal Repertoire of Infants ${ }^{1}$
}

\author{
Thaise Löhr \\ Universidade Federal de São Carlos, \\ São Carlos-SP, Brazil
}

\author{
Maria Stella Coutinho de Alcantara Gil \\ Universidade Federal de São Carlos, \\ São Carlos-SP, Brazil
}

\begin{abstract}
To refer to an object or event by providing its corresponding name is an important acquisition in the learning of verbal behavior. The relationship between the spoken name and its referent, called tact, is considered essential in the expansion of verbal repertoires in children. This study aimed to teach tact to four institutionalized children, aged between 26 and 29 months, with reduced exposure to verbal stimulation. The procedure introduced playful characteristics into the teaching of tact and the required repertoire, which was the emission of echoic responses, through procedures typically used to teach verbal repertoire for children with language delay. All children learned to tact (and echo). The procedure was effective in increasing the echoic repertoire and promoting the acquisition of the tact repertoire. These results confirm the literature that considers learning echoic repertoire to be a requirement for the acquisition of tact.
\end{abstract}

Keywords: verbal communication, tactual perception, children recreational games

\section{Aprender Brincando: Ecoar e Tatear na Ampliação do Repertório Verbal de Bebês}

\begin{abstract}
Resumo: Referir-se ao objeto ou evento dizendo o nome correspondente é uma importante aquisição na aprendizagem do comportamento verbal. A relação entre o nome falado e seu referente, denominada tato, é considerada imprescindível na ampliação de repertórios verbais das crianças. Este trabalho teve por objetivo ensinar a tatear a quatro crianças acolhidas judicialmente, com reduzida exposição à estimulação verbal e com idades entre 26 e 29 meses. O procedimento introduziu características de brincadeira no ensino do tato, e do repertório requisito que era a emissão de reposta ecoica, em procedimentos empregados no ensino de repertório verbal para crianças com atraso de linguagem. Todas as crianças aprenderam a tatear (e ecoar). O procedimento foi eficaz para incrementar o repertório de ecoar e promover a aquisição do repertório de tatear. Os resultados confirmam a literatura que considera a aprendizagem de repertório ecoico como requisito na aquisição do tato.
\end{abstract}

Palavras-chave: comunicação verbal, percepção tátil, jogos infantis

\section{Aprender Jugando: Resonar y Tantear en la Ampliación del Repertorio Verbal de Bebés}

\begin{abstract}
Resumen: Una adquisición importante en el aprendizaje del comportamiento verbal es la de referirse al objeto o evento diciendo el nombre correspondiente. La relación entre el nombre hablado y su referente fue denominada tacto y es considerada imprescindible en la ampliación de repertorios verbales de los niños. El objetivo de este estudio fue enseñar cuatro bebés acogidos judicialmente a tantear, con exposición reducida a la estimulación verbal y con edades entre 26 y 29 meses. El procedimiento introdujo características de juego en la enseñanza del tacto y del repertorio requisito, que era la emisión de respuesta ecoica, en procedimientos empleados en la enseñanza de repertorio verbal para niños con atraso de lenguaje. Todos los niños aprendieron a tantear. El procedimiento fue eficaz para incrementar el repertorio del resonar y promover la adquisición del repertorio de tantear. Los resultados confirman la literatura que considera el aprendizaje del repertorio resonar como requisito para la adquisición del tacto.
\end{abstract}

Palabras clave: comunicación verbal, percepción táctil, juegos infantiles

In 1957, Skinner defined verbal behavior as a particular type of operant behavior, which is reinforced through the mediation of other people who have been specially prepared

\footnotetext{
Article derived from the Master's thesis of the first author under the supervision of the second, defended in 2011, in the Graduate Program in Psychology of the Universidade Federal de São Carlos.

Support: Coordination for the Improvement of Higher Education Personnel - National Institute of Science and Technology - CAPES/INCT, National Institute of Science and Technology on Behavior, Cognition, and Teaching - INCT-ECCE (Relational Learning and Symbolic Functioning - 2009-2015), São Paulo Research Foundation - FAPESP (Protocol no. 2008/57705-8), and National Council for Scientific and Technological Development - CNPq (Protocol no. 573972/2008).

2 Correspondence address:

Thaise Löhr. Avenida Cândido Hartmann, 570, conjunto 311-312. Champagnat. CEP 80730-440. Curitiba-PR, Brazil. E-mail: thaiselohr@gmail.com
}

to act as mediators. In this formulation the author explains some contingencies that describe the verbal behavior and states that verbal responses depend on an audience which can produce effects on the speaker. The interaction between this audience and the learner establishes the control relationships of which the verbal behavior of the learner is a function. The different control relationships define the verbal operants that compose the speaker and listener repertoire.

Studies regarding the acquisition of the verbal repertoire in young children show that the first verbal operants learned are the echoic, mand and tact (Greer \& Ross, 2008; LeBlanc, Dillon, \& Sautter, 2009; Partington, Sundberg, Newhouse, \& Spengler, 1994). Similarly, the study of Cruvinel (2010) recorded the interactions of a child with its caregivers between 18 and 24 months of age. Data analysis indicated 
that, from 20 months of age, there was a sharp increase in the tacts, mands, echoics and intraverbals of the child and the companion. Aiming to induce and expand the verbal repertoire, Greer and Ross (2008) described the process for teaching each verbal operant and mentioned that tact is considered a more complex verbal operant requiring the echoic and listener repertoires.

The echoic response is usually the first verbal operant to be learned and the critical factor is in the point-to-point correspondence between the auditory model provided by the speaker and the sound emission of the listener (Skinner, 1957). The learning of echoics by the child depends on the adult arranging contingencies that put the vocal response of the child under the control of the relevant conditions of the environment, as in the example where the speaker emits the answer "woof woof" when presented with the dog after hearing someone say "woof woof" (Cruvinel \& Hubner, 2013; Greer \& Ross, 2008; Skinner, 1957).

To install and increase the echoic repertoire is a requisite for learning tact. By acquiring the echoic repertoires, the child is able to say words and learn new tacts. Considering the progression of the complexity of verbal behavior acquisition, the present study taught behaviors considered prerequisites for the acquisition of tact, this being the echoic repertoire (Greer \& Speckman, 2009).

One of the ways in which the verbal community provides consequences for the sound reproduction is by making use of what Skinner (1957) called "educational reinforcement" (p. 56). This expression was used to refer to the consequences that parents and teachers provide for the performance of the children when faced with the task of inserting them into the verbal community. When dealing with the establishment of the echoic repertoire, the usefulness of educational reinforcement is highlighted by the use of the mand "Say X", where X is the word to be echoed. That is, the verbal community, in this case the parents and teachers, reinforces the echoic behavior emitted by the child.

A rudimentary analysis of the effects of the echoic suggests that the one that echoes listens to him/herself. Thus, the echoic response emitted triggers the auditory and phono-articulatory systems of the listener, producing changes in the proprioceptive stimuli of the person that echoes. With the development of the echoic repertoire, when hearing its own emission of the echoic, the infant would be able to note the similarity between the auditory pattern emitted when echoing and that emitted by the model. The recognition of the sound proximity of the word/stimulus and of the word produced in the echo response would depend on the approval of the audience in the so-called "educational reinforcement" (Skinner, 1957, p. 56). The control relationship between the word emitted by the speaker and the word reproduced by the listener is established by the verbal community. In this case, educational reinforcement creates the conditions for the development of the competent echoic repertoire by defining the requirements of similarity between the model and sound production in the echo.

As with the echoic, tact has a prominent role in the teaching of verbal behavior for young children and is considered one of the most important acquisitions when it comes to expanding or installing new verbal repertoires (Cruvinel \& Hubner, 2013). The acquisition of tact puts the vocal verbal repertoire of the child under the control of a specific antecedent stimulus - a particular object, event or property of an event, which exercises a discriminative function (Skinner, 1957). The antecedent stimulus evokes or strengthens the vocal/gestural response (in the case of sign language) that was conventionally defined by the social group. The relationship established thus specifies the topography of a verbal response, under the control of a specific non-verbal antecedent stimulus, which result in one or more generalized conditioned reinforcing stimuli. The generalized reinforcement is a consequence that the verbal community usually provides during the acquisition of tact, being defined by Ferster and Perrot (1968) as a kind of conditioned reinforcer in which different behaviors can have different types of reinforcers. The strength of the response of the learning child is mainly determined by the responses emitted by the adult that provides the consequences (Skinner, 1957).

Several studies have analyzed the role of the adult in proposing appropriate teaching conditions (Cruvinel, 2010; Gil, Oliveira, Sousa, \& Faleiros, 2006; Greer \& Ross, 2008; LeBlanc et al., 2009; Sousa, Souza, \& Gil, 2013), planning the teaching so that the child is exposed to the stimulus for a determined number of times (Antoniazzi, Domeniconi, \& Schmidt, 2014; Gurteen, Horne, \& Erjavec 2011; Sousa et al., 2013) and also as a provider of the conditions subsequent to the response(s) that are reinforcers (Gil, Oliveira, \& McIlvane, 2011; Sousa, Garcia, \& Gil, 2014). In the study reported here, the adult that proposes appropriate teaching conditions is represented by the researcher, who adopted a favorable method for the study and, simultaneously, needed to consider the requirements of the target population, since they were children at risk of social vulnerability.

The overall aim of this study was to teach vocal tact to four children institutionalized under the care of the social services, with restricted exposure to verbal stimulation, in a playful context, in which the situation of play predominated. The procedures described by Greer and Ross (2008), for teaching the verbal repertoire to children with language delays, were the reference for planning the procedure for the children with typical development, in an institutionalized situation. In this context, there is a high proportion of children per adult, reducing the opportunities to establish verbal interactions that promote the acquisition of verbal behavior by the young children.

The teaching of tact to the institutionalized children interspersed requests for echoic and tact responses 
(Echoic-to-tact, p. 60) and, in the present study, tact was taught in a context of play after adaptating one of the subcomponents of the verbal milestones described by Greer and Ross (2008). It is important o highlight that, in all of the teaching procedures, play was the result of the realization of the task and the prime reinforcing consequence throughout the entire study. This decision originated from studies in which variables that favored the organization of the experimental environment for the study of basic processes with young children were controlled (Gil et al., 2006; Gil, Oliveira et al., 2011; Gil, Sousa, \& Souza, 2011; Silva \& Souza, 2009). Therefore, it was decided to teach tact aiming to: amplify the verbal repertoire of the children; establish control relationships of the verbal response of the children through the antecedent stimuli of the environment.

\section{Method}

\section{Participants}

The study participants were three girls $(\mathrm{J}, \mathrm{P}, \mathrm{T})$ and one boy (K), respectively aged 29, 26, 26 and 28 months (J29; P26; T26; K28). According to the Denver II Developmental Screening Test evaluation, the participants showed development compatible with their age group.

All participants were in a temporary living arrangement where they were under protection while awaiting a judicial decision, either for reintegration into their families or placement with foster families (adoption). The performance of the study with the children was authorized by the directors of the institution, who were the legal guardians during the institutionalization period. In this environment the children had a limited exposure to verbal stimulation, due to the low proportion of adults caring for them.

\section{Instruments}

Denver II Developmental Screening Test (Pedromônico, Bragatto, \& Strobilus, 1999). It was used to identify late development or the need for care in relation to the development. It consists of 125 items, distributed to evaluate four distinct functions of the neuro-psychomotor development: language, gross motor, fine motor adaptive and personal-social.

Stimuli. Objects familiar to the participants and objects made to exercise the arbitrary stimuli function were used. The following objects were used as the familiar objects: spoon, plate, shirt, comb, brush, shoe. In the case of the arbitrary stimuli, objects were created and made of soft felt, with solid colors and geometric forms, to which eyes, mouth, arms and legs were added. The name (auditory stimulus) was arbitrarily assigned to each object and was formed by the repetition of a syllable (tata, lili, dudu, lolo). These names were the words taught to the children, with Lili and Tata being taught for the four children and Dudu and Lolo just for boy K28. Tacts were taught for the familiar and arbitrary objects, mentioned above. Industrialized toys were also used to carry out the function of creating different contexts for the teaching of tact, selected according to the age group of the participants.

Video recorder. A mini digital video recorder SMX-C10 and a Sony computer were used for recording.

\section{Procedure}

Data collection. Data collection was performed in an Institutional Care Unit, located in a large city of Paraná state. The sessions were conducted in a visitor's room of the institution, with the usual furniture and natural lighting and ventilation.

Prior to data collection, there was a period of familiarization between the experimenter and the children during which the Denver II Screening Test was applied and the familiar stimuli were identified. Familiar stimuli were considered to be those for which the children did not say the name, however, took when requested by the adult, for example: "where's the spoon?".

Data collection lasted ten weeks for $K 28$ and $J 29$ and five weeks for T26 and P26. The duration of the sessions ranged from four to 25 minutes. The variation in the length of the sessions was due to the following criteria for concluding the session: to present indications of fatigue or to achieve the learning criterion of three consecutive correct responses.

The general teaching procedure was composed of two types of request/instruction (mand of the researcher): request/instruction of the adult for echoic responses of the child and request/instruction of the adult for vocal tact responses of the child. The number of requests for each type ranged from three to 26 per session. The tacts were first taught for the familiar objects and, in sequence, for the constructed (arbitrary) objects. The pairs of arbitrary stimuli were used in order to ensure that the performance of the child was only due to the tact teaching sessions and not the stimulation of the environment.

In this study, the teaching of two pairs of familiar stimuli for each child was performed for three of the four children. This was not possible for one of the children (J29) as the child was going to leave the institution within a short period, therefore, instead of teaching the second pair of familiar stimuli the first pair of arbitrary stimuli was taught. The number of pairs of arbitrary stimuli exposed for each child varied depending on the time that the child took to tact the objects; the first pair was taught for the four children, while the second pair was exposed only to one child (K28), who performed well and produced the tact response before the others.

For K28, there were 17 sessions and eight words were taught (spoon, plate, shirt, comb, Lili, Tata, Dudu, Lolo); for J29 four words were taught, over 19 sessions, (spoon, plate, Lili, Tata); for participated T26 six words were taught, over 14 sessions (spoon, plate, brush, comb, Lili, Tata); and finally for P26 six words were taught, over 10 sessions (spoon, plate, shoe, comb, Lili, Tata). 
The teaching procedure was carried out in two steps, as described below. These steps were carried out in sequence, i.e., soon after the echoic response request, the tact response was requested.

Echoic repertoire teaching. After ensuring that the child was under the control of the stimulus, i.e., was looking in the direction of the object, an echoic response was requested. The echoic response request consisted of the presentation of the object simultaneously to the paused emission of the corresponding name. Any approximate emission of the target word was followed by generalized social reinforcement and the functional use of the object in play. The requirement was increased progressively in relation to the child's response until the child was able to correctly echo the word emitted by the adult.

Vocal tact teaching. The teaching of tact corresponded to the procedure adopted by Greer and Ross (2008), in which Instructions/Questions (mands of the adult) were formulated simultaneously to the presentation of objects. The procedure required the child to correctly say the name of an object when asked. The object could be in the hand of the experimenter, in the hand of the child or on the floor. Questions such as "what is this?" were made at the same time that the researcher brought the object near to the child or pointed to it. The correct response of vocal tact was followed by clapping, praise and kisses and included the child and the researcher playing with the toys or the arbitrary objects. In the case of wrong responses the experimenter repeated the echoic response request. The learning criterion of the name-object relationship was the correct emission of the name of the object by the child in three consecutive trials and the criterion to end the session was an indication of fatigue on behalf of the participant. The number of consecutive correct responses could vary beyond three correct responses, as could the number of trials per session. However, the requirement to consider that the relationship taught had been learned was the occurrence of at least three consecutive correct responses.

Data analysis. The video recordings of all sessions were fully transcribed following the chronological order of the events. The instructions given were categorized in relation to the specific repertoire request: to provide an echoic response and tact response. Following this, descriptive statistical analysis was performed, illustrating the relative frequencies of the total requests made by the researcher with the frequency of correct responses of the children.

\section{Ethical Considerations}

The study met the ethical requirements and was approved by the Human Research Ethics Committee of the Universidade Federal de São Carlos (Protocol no. 455/2009 - CAAE 3479.0.000.135-09).

\section{Results}

All participants learned to name (tact) at least two objects. One participant learned to tact eight objects, two participants learned to tact six objects and one participant learned to tact two objects. Figures 1 and 2 show the cumulative curve of the requests of the experimenter and of the correct responses of each of the four participants, respectively, for the emission of echoic and tact responses. The sessions were grouped according to time.

By comparing the curves that describe the number of requests of the experimenter with the corresponding curves of the correct responses of the infants, in the echoic and tact teaching procedures, a general trend of compliance of the children to the adult requests was observed. For three of the four participants, the line corresponding to the emission of echoic responses accompanied that of the requests, indicating that the three children accurately responded to the requests of the adult, i.e., that this pre-existing repertoire was only being incremented (Figure 1). Only one participant, T26, did not provide echoic responses for the initial requests, allowing the affirmation that the acquisition of the echoic depended, at least partially, on the exposure to the procedure. In the first exposure to the stimulus, participant T26 did not issue the responses requested and the re-exposure to the models produced oral emissions almost simultaneous to the model emissions and close to the word spoken by the researcher, throughout the procedure.

Table 1 describes, for each child, the pairs of stimuli taught and the number of sessions necessary for the child to achieve the learning criterion for the pair. The total number of teaching sessions and the exposure to stimuli pairs varied among the participants. With respect to the pairs of arbitrary stimuli, for three participants (K28, T26 and P26), on average, seven sessions were required. Participant J29 achieved the learning criterion in four sessions for the arbitrary pair.

There was variation among the subjects in relation to: the length of the sessions, the number of sessions necessary for learning, and the number of pairs of stimuli taught, as can be seen in Figures 1 and 2 and in Table 1. The pairs were taught simultaneously. Figures 1 and 2 present the results of the cumulative curve of all the pairs in sequence. Regarding tact, it was noted that the cumulative frequency of requests by the researcher was increasing with a positive acceleration. The repertoire of all the children generally began low, however, with exposure to the teaching procedure an inflection in the curve was noted, which appears to suggest the acquisition of the tact repertoire through exposure to the requests of the researcher. Thus, it was noted that the greater difference between the demands of the experimenter and the correct responses of the infants was relative to the tact: the number of initial correct responses was low for the four participants, with progressive increases in the correct responses, indicating that the acquisition of the tact repertoire was a result of the exposure to the teaching procedure (Figure 2). It should be noted that the cumulative frequency of requests by the researcher was increasing, producing a positively accelerated curve. All the children began the teaching situations with few correct responses. 

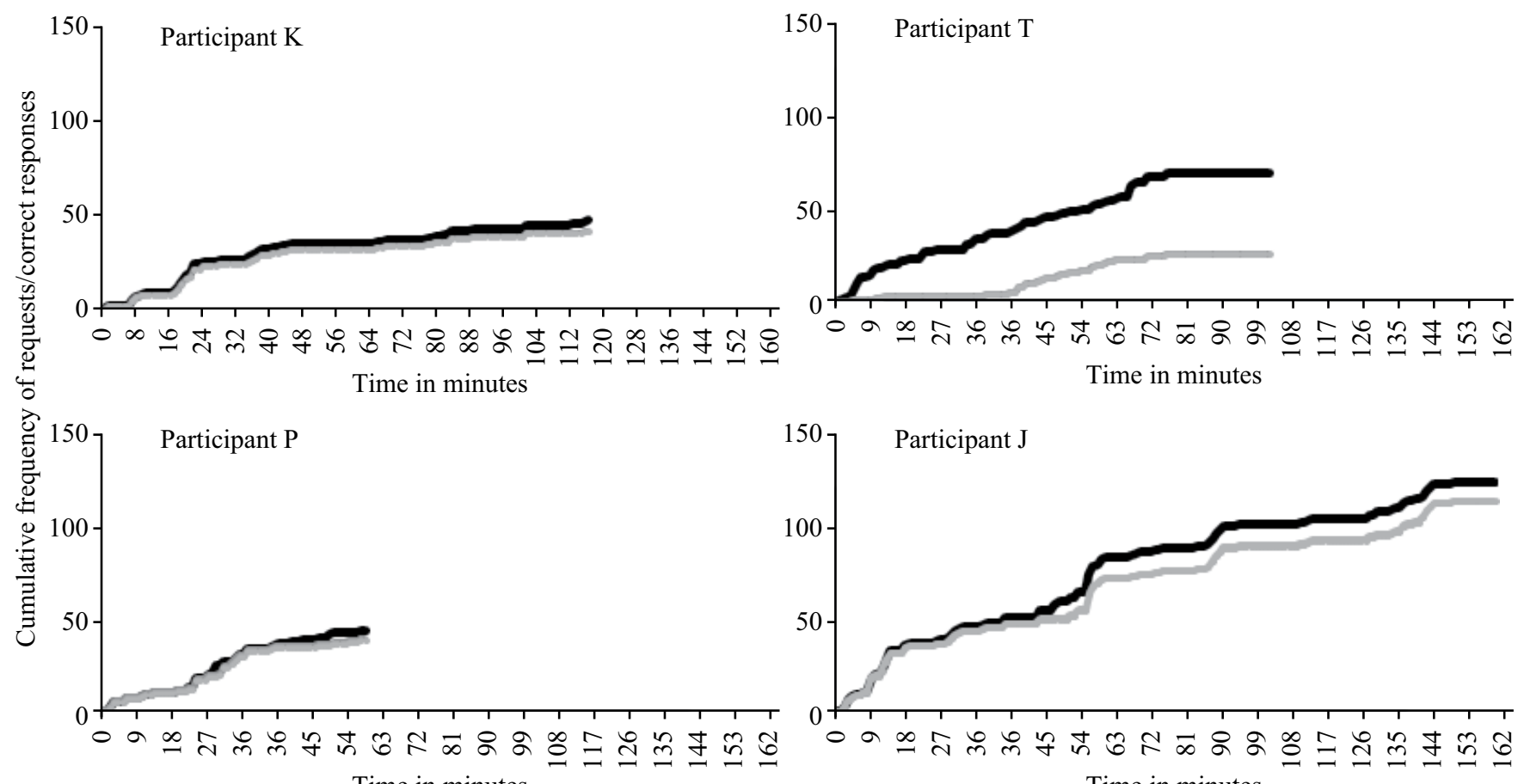

Time in minutes

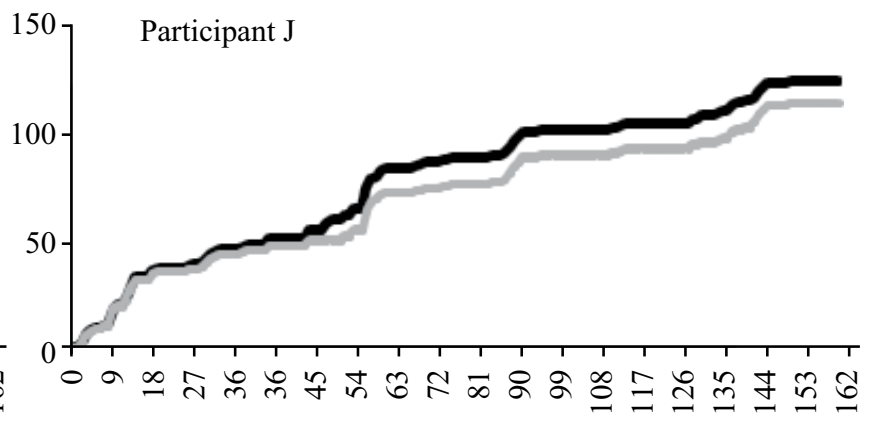

Echoic Request

Echoic Response

Figure 1. Cumulative curves of echoic requests and the corresponding correct response curves for each participant. Cumulative curves of requests of the experimenter and of correct echoic responses of each of the four participants. The black curve shows the cumulative frequency of requests of the experimenter; the gray curve illustrates the frequency of correct responses of the participants.
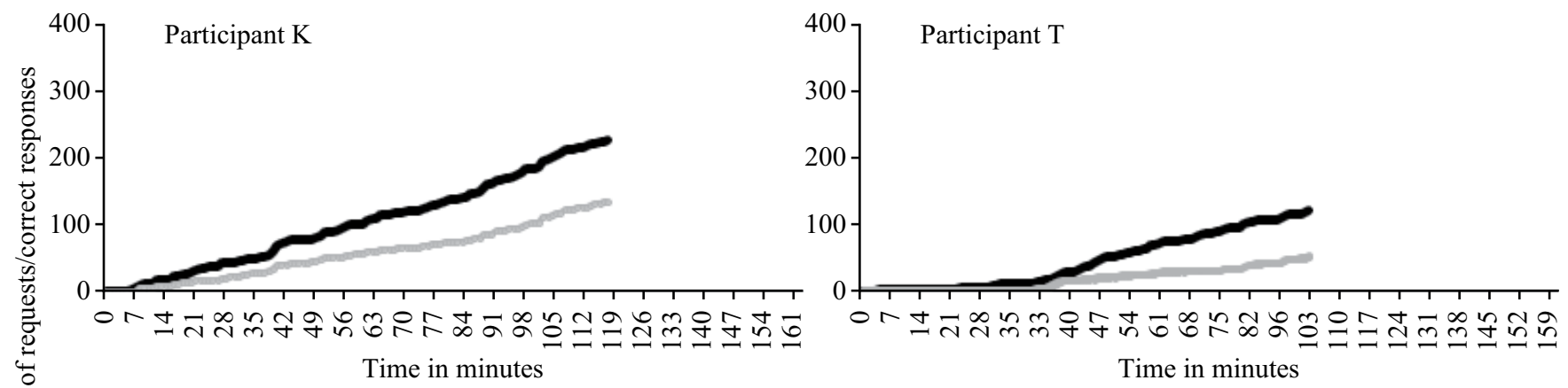

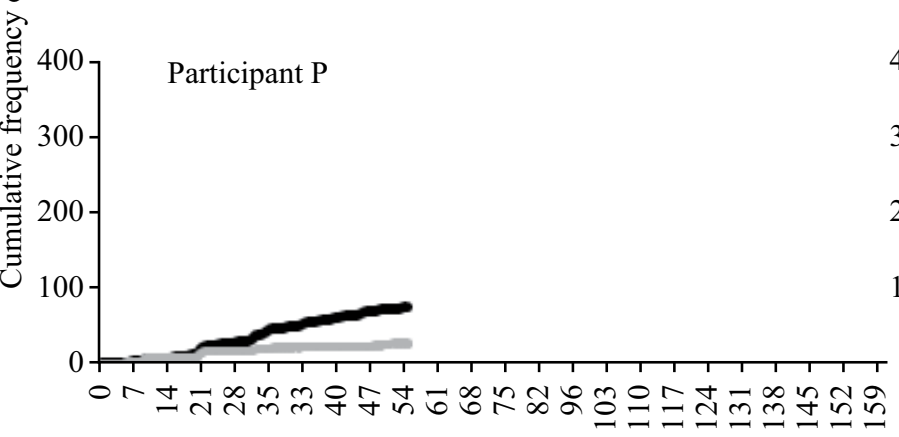

Time in minutes

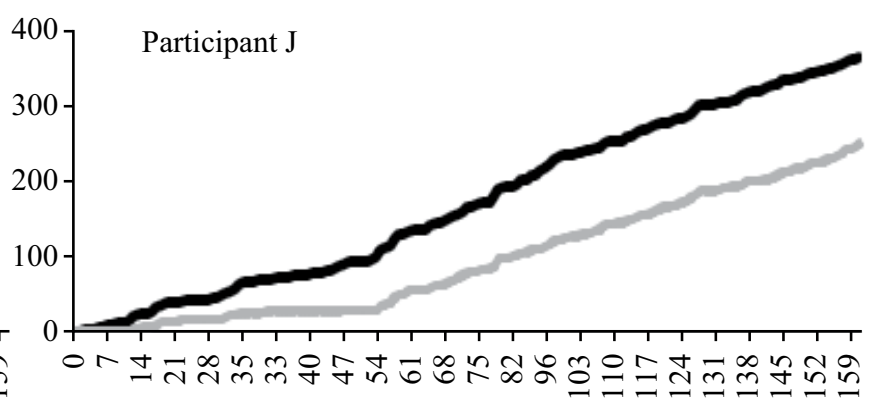

Time in minutes

Tact Request

Tact Response

Figure 2. Cumulative curves of tact requests and the corresponding correct response curves for each participant. Cumulative curves of requests of the experimenter and of correct tact responses of each of the four participants. The black curve shows the cumulative frequency of requests of the experimenter; the gray curve illustrates the frequency of correct responses of the participants. 
Table 1

Participants, Stimuli Pairs and Total Sessions by Participant

\begin{tabular}{lccc}
\hline \multirow{2}{*}{ Participants } & Stimuli pairs per session & $\begin{array}{c}\text { Sessions } \\
\text { No. to criterion }\end{array}$ & Total \\
\hline P & P1F: spoon/plate & 2 & 10 \\
& P2F: shoe/comb & 2 & \\
& P3A: lili/tata & 6 & \\
$\mathrm{~T}$ & P1F: spoon/plate & 3 & 14 \\
& P2F: brush/comb & 3 & \\
& P3A: lili/tata & 8 & \\
K & P1F: spoon/plate & 2 & 17 \\
& P2F: shirt/comb & 3 & \\
& P3A: lili/tata & 8 & \\
J & P4A: dudu/lolo & 4 & \\
& P1F: spoon/plate & 15 & \\
& P2A: lili/tata & 4 &
\end{tabular}

Note. With respect to the pairs of stimuli, $\mathrm{P}$ followed by the number denotes the teaching order of a pair of stimuli, the letter $F$ refers to the familiar stimuli and the letter A to the arbitrary stimuli.

The inflection in the curve (when the curves did not present differences, between the experimenter request line and the correct response line) indicates that exposure to the teaching procedure was related to the change in the tact repertoire.

\section{Discussion}

A trajectory of learning was established with the goal of teaching tact to four institutionalized children (with reduced exposure to verbal stimulation), aged between 26 and 29 months. Despite the echoic response being part of the speaker repertoire, it has a lower degree of difficulty than the tact response, since there is point-to-point correspondence between the verbal response of the child and the auditory verbal stimulus presented (Skinner, 1957). The teaching of tact was therefore carried out through listener response requests interspersed with speaker response requests (echoic and tact).

The four participants presented a progressive increase in correct responses corresponding to the number of echoic requests. Comparing the responses in the echoic teaching with those of the tact teaching, it was verified that the children responded proportionately more to the echoic emission requests than to the tact emission requests. These results corroborate the claim of Cruvinel and Hubner (2013) that the significant increase in the cumulative frequency of the emission, by the child, of the tact, mand and echoic categories is linked to the increase of the emissions of these categories by the adult. Cruvinel and Hubner found that, at the same rate that the parents increased the mand and echoic requests, the child increased the emission of those behaviors. Greer and Ross (2008) affirmed that tact can be considered the most complex verbal repertoire compared to the echoic repertoire and that this is required performance for the learning of tact.
A marked difference was found between the tact emission requests and the correct responses of the infants (Figure 2). In the initial performance of the infants there was a significantly lower number of correct responses in relation to the requests made, observing the increase in correct emissions over the exposure to the tact teaching condition, expressed in the cumulative curves of requests and correct responses (Figure 2). This data can contribute to reaffirm that tact is a more complex repertoire compared to the echoic repertoire, demanding a higher number of exposures to tact opportunities (Greer \& Ross, 2008). Learning vocal tact requires long periods of intensive teaching, with repeated exposures to the appropriate control conditions.

The data also suggest that the echoic emission requests were facilitating the learning of tact by installing a required repertoire. The findings converge with the proposal of Greer and Ross (2008) and confirm the need for a history of intensive exposure to the stimuli, in constant interaction with the verbal community for the acquisition of speaker behavior (Skinner, 1957).

The tact teaching procedure used in this study has another characteristic that brings it together with the conditions that the verbal community provides for its learners. By exposing the participants to two teaching conditions they can learn under two contingencies, a situation that resembles the everyday learning of verbal behavior. This condition was predicted by Arntzen and Almas (2002), and Carroll and Hesse (1987), for whom conditions for co-operative learning of two operants can facilitate the acquisition of one of them.

The efficacy of the planned teaching conditions, indicated by the learning of tact by the four participants, may also be related to the playful character of the procedures. In addition to some similarity to the practices of the verbal community, the use of play was another aspect to be considered. Some studies (Bruner, 1983; Gil \& Rose, 2003; Rose \& Gil, 2003) emphasized the role of play as a learning context by highlighting that many important activities in adult life are developed and practiced in play situation. It is also in play that children perform the role of speaker and modify the behavior of others, as well as benefit from instructions given by others and improve their listening skills. Considering the importance of teaching in play contexts, some studies were conducted with procedures similar to the play context and produced effective results regarding the efficacy of learning in this context (Gil et al., 2006; Sousa, 2009).

Adult play with children also refers to the role of adults in the acquisition of language by young children. Parents or close adults progressively increase the demand for more sophisticated performances from young learners, as verified by Bruner (1983). Simultaneously to demanding more and better verbal performance from the children, the parents or close adults are an important source of reinforcers during the development of the children. However, the children in the present study, not only did not live or have any contact with their parents, but were also housed in an environment with 
a low proportion of adults to care for them. Lack of contact with parents and the reduced opportunities for contact with the adult caregiver greatly increase the condition of deprivation of attention.

The adult/experimenter, in this study, had an important role in planning the teaching, arranging the contingencies for the learning of the children, proposing teaching conditions similar to play, being the audience while playing the role of listener prepared to reinforce the behavior of the speaker and being the source of important reinforcers. This combination of factors may have contributed to the effectiveness of the vocal tact teaching procedure and establishment of this repertoire, which is in line with the results of studies that examined the adult role in proposing appropriate learning conditions for children (Cruvinel, 2010).

The present study highlights the importance of the teaching procedure designed to install a new verbal repertoire in the children. With regard to the learning of tact, the results indicated that the initial number of correct responses was low for the four participants, with the progressive increase in correct responses indicating that the acquisition of the tact repertoire was due to exposure to the teaching procedure. The tact teaching situation included, simultaneously and over time, the learning of various different verbal relationships.

This study contributes to the planning of teaching of new verbal repertoires for infants, in this case the echoic and tact repertoires. The procedure is easy to use, can be adopted in institutions without requiring expensive equipment or objects, and allows the promotion of language acquisition for institutionalized children. It is suggested for future research, that this same procedure is replicated both with different populations, to control variables of the characteristics of the study participants, as well as with small groups of children, aiming to improve the learning conditions in institutions with a high proportion of children per adult. If further studies using this procedure obtain positive results, then in the future this procedure may be organized into an instruction protocol for the expansion of the verbal repertoire. For future studies, that have infants in an institutionalized situation as participants, expanding the sample to verify the generality of the result is suggested.

From the perspective of the relationship of the child with the verbal community, there would be an order to the acquisitions in which the echoic would be a condition for the acquisition of tacts and mands. The tacts and mands could be installed through various combinations of contiguous or simultaneous temporal acquisition, i.e., they may be acquired concurrently, while the echoic would be a requirement for the acquisition of tact. Regarding a favorable sequence for the acquisition of tact, some authors consider that when planning the development of the verbal repertoire, the teaching of the echoic repertoire must precede the teaching of tact (Greer \& Ross, 2008).

In this study, the unequal number of requests of the experimenter in the tact teaching procedure can be considered a methodological limitation. As the literature has few studies in this area, further studies are necessary that control the following variables: an equal number of presentations and sessions for each stimulus and an equal amount of exposure to the teaching of echoic and tact. These controls would allow verification of the tact learning process and affirmation that the procedure used is effective for teaching tact and for the expansion of the verbal repertoire of children at risk of social vulnerability.

\section{References}

Antoniazzi, M., Domeniconi, C., \& Schmidt, A. (2014). Efeito da pré-exposição ao objeto no desempenho da exclusão e na aprendizagem da relação nome-objeto. Acta Comportamentalia, 22(1), 23-36.

Arntzen, E., \& Almas, I. K. (2002). Effects of mand-tact versus tact-only training on the acquisition of tacts. Journal of Applied Behavior Analysis, 35(4), 419-422. doi:10.1901/jaba.2002.35-419

Bruner, J. (1983). Child's talk: Learning to use language. New York, NY: W. W. Norton.

Carroll, R. J., \& Hesse, B. E. (1987). The effects of alternating mand and tact training on the acquisition of tacts. The Analysis of Verbal Behavior, 5, 55-65.

Cruvinel, A. C. (2010). Análise da aquisição de comportamento verbal em uma criança dos dezoito meses aos dois anos de idade (Doctoral dissertation). Retrieved from http://www.teses.usp.br/teses/ disponiveis/47/47132/tde-08092010-150927/pt-br.php

Cruvinel, A. C., \& Hubner, M. M. C. (2013). Analysis of the acquisition of verbal operants in a child from 17 to 2 years of age. The Psychological Record, 63(4), 735-750. doi:10.11133/j.tpr.2013.63.4.003

Ferster, C. B., \& Perrot, M. C. (1968). Behavior principles. New York, NY: Appleton- Century-Crofts.

Gil, M. S. C. A., Oliveira, T. P., \& Mcllvane, W. J. (2011). Conditional discriminations by preverbal children in an identity matching-to-sample task. The Psychological Record, 61(3), 327-340.

Gil, M. S. C. A., Oliveira, T. P., Sousa, N. M., \& Faleiros, D. A. M. (2006). Variáveis no ensino de discriminação para bebês. Psicologia: Teoria e Pesquisa, 22(2), 143-152. doi: $10.1590 /$ S0102-37722006000200003

Gil, M. S. C. A., \& Rose, J. C. C. (2003). Regras e contingências sociais na brincadeira de crianças. In M. Z. S. Brandão, F. C. S. Conte, F. S. Brandão, Y. K. Ingberman, C. B. Moura, V. M. Silva, \& S. M. Oliane (Orgs.), Sobre comportamento e cognição (Vol. 11, pp. 383-389). Santo André, SP: ESETec.

Gil, M. S. C. A., Sousa, N. M., \& Souza, D. G. (2011). Dois procedimentos para introduzir reforçamento diferencial no ensino de discriminações simples a bebês. Acta Comportamentalia, 19(2), 163-182. Retrieved from http://pepsic.bvsalud.org/pdf/actac/v19n2/a03.pdf 
Greer, R. D., \& Ross, D. E. (2008). Verbal behavior analysis: Inducing and expanding new verbal capabilities in children with language delays. Upper Saddle River, NJ: Pearson Education.

Greer, R. D., \& Speckman, J. M. (2009). The integration of speaker and listener responses: A theory of verbal development. The Psychological Record, 59(3), 449-488.

Gurteen, P. M., Horne, P. J., \& Erjavec, M. (2011). Rapid word learning in 13- and 17-month olds in a naturalistic two-word procedure: Looking versus reaching measures. Journal of Experimental Child Psychology, 109(2), 201-217. doi:10.1016/j.jecp.2010.12.001

LeBlanc, L. A., Dillon, C. M., \& Sautter, R. A. (2009). Establishing mand and tact repertories. In R. A. Rehfeldt \& Y. Barnes-Holmes (Eds.), Derived relational responding: Applications for learners with autism and other developmental disabilities: A progressive guide to change (pp. 79-108). Oakland, CA: New Harbinger.

Partington, J. W., Sundberg, M. L., Newhouse, L., \& Spengler, S. M. (1994). Overcoming an autistic child's failure to acquire a tact repertoire. Journal of Applied Behavior Analysis, 27(4), 733-734. doi:10.1901/jaba.1994.27-733

Pedromônico, M. R. M., Bragatto, E. L., \& Strobilus, R. (1999). Teste de Triagem Denver II. São Paulo, SP: Unifesp.

Rose, J. C. C., \& Gil, M. S. C. A. (2003). Para uma análise do brincar e de sua função educacional: A função educacional do brincar. In M. Z. S. Brandão, F. C. S. Conte, F. S. Brandão, Y. K. Ingberman, C. B. Moura, V. M. Silva, \& S. M. Oliane (Orgs.), Sobre comportamento e cognição (Vol. 11, pp. 373-382). Santo André, SP: ESETec.

Silva, F. T. N., \& Souza, C. B. A. (2009). Discriminação simples com mudanças sucessivas na função dos estímulos: Aprendizagem em bebês. Psicologia: Teoria e Pesquisa, 25(4), 569-580. doi:10.1590/S0102-37722009000400012

Sousa, N. M. (2009). Identificação de condições eficientes no ensino de discriminações para bebês com até 24 meses (Unpublished master's thesis). Universidade Federal de São Carlos, São Carlos, SP.

Sousa, N. M., Garcia, L. T., \& Gil, M. S. C. A. (2015). Differential reinforcement in simple discrimination learningin 10-to20-month-old toddlers. The Psychological Record, 65(1). doi:10.1007/s40732-014-0081-4

Sousa, N. M., Souza, C. B. A., \& Gil, M. S. C. A. (2013). Aprendizagem rápida de comportamento ouvinte por um bebê. Interação em Psicologia, 17(1), 67-78. doi:10.5380/psi.v17i1.28205

Skinner, B. F. (1957). Verbal behavior. Englewood Cliffs, NJ: Prentice Hall.
Thaise Löhr is an Assistant Professor of the Faculdade Evangélica do Paraná.

Maria Stella Coutinho de Alcantara Gil is an Associate Professor of the Universidade Federal de São Carlos.

Received: June 3, 2014

1st Revision: Oct. 28, 2014

2nd Revision: Dec. 5, 2014

Approved: Dec. 18, 2014

How to cite this article:

Löhr, T., \& Gil, M. S. C. A. (2015). Learning by playing: Echo and tact in expanding the verbal repertoire of infants. Paidéia (Ribeirão Preto), 25(60), 77-84. doi: 10.1590/1982-43272560201510 


\section{Erratum}

In the article "Learning by Playing: Echo and Tact in Expanding the Verbal Repertoire of Infants" published in the journal Paidéia (Ribeirão Preto), 25(60), 77-84, on page 84, for:

"Faculdade Evangélica do Paraná."

read:

"Pontifícia Universidade Católica do Paraná." 